\title{
Extreme Bed Changes in the Gaoping River Under Climate Change
}

\author{
Yi-Chiung Chao *, Hsin-Chi Li, Jun-Jih Liou, and Yung-Ming Chen \\ National Science and Technology Center for Disaster Reduction, New Taipei City, Taiwan, R.O.C.
}

Received 17 June 2015, revised 31 December 2015, accepted 30 June 2016

\begin{abstract}
Extreme typhoon events have been increasing due to climate change. In recent years, severe landslides, flooding, and extreme sediment transport have become more easily induced by these events. This study employs dynamic downscaling climate projection data to evaluate riverbed changes and sediment transport processes of the Gaoping River, located in southern Taiwan, under the worst late $20^{\text {th }}$ century conditions and projections for the late $21^{\text {st }}$ century. Results show that the peak runoff discharge in the late $21^{\text {st }}$ century could be 1.48 times larger than that in the late $20^{\text {th }}$ century. This data indicates that the risk potential for overbank and pier scour disasters will increase in the future. However, in contrast to the late $20^{\text {th }}$ century, the thalweg sediment aggradation model indicated $19 \%$ less in the late $21^{\text {st }}$ century. An experimental design method was applied to further explore the reasons behind this outKome. It was found that severe riverbed changes correlated negatively with the peak discharge in extreme floods. These findings will greatly assist in understanding riverbed change processes under extreme typhoon events using dynamic downscaling climate change data.
\end{abstract}

Key words: Dynamic downscaling, Extreme typhoon events, Critical discharge, Bed change processes

Citation: Chao, Y. C., H.C. Li, J. J.Liou, and Y. M. Chen, 2016: Extreme bed changes in the Gaoping River under climate change. Terr. Atmos. Ocean. Sci., 27, 717-727, doi: 10.3319/TAO.2016.06.30.03

\section{INTRODUCTION}

Recurrent typhoons and heavy rainfall events have repeatedly induced severe sediment disasters in mountain areas and flooding events along the Goaping River in recent years. The Goaping River is the longest river in southern Taiwan, with the Cishan, Laonong, and Ailiao Rivers as its three major tributaries (Fig. 1a). According to disasterrelated data and statistics from 2008 (Typhoon Kalmaegi) to 2010 (Typhoon Fanapi), 233 flooding events occurred in the Gaoping Watershed (NCDR 2015), with Typhoon Morakot in 2009 causing the worst damage. The "Disaster Survey and Analysis of Morakot Typhoon" report indicated that Typhoon Morakot induced embankment damage, floods, and bridge fractures (MOST 2010). A total of 12697 landslides were triggered, including four giant landslides. The landslide ratio in the Gaoping Watershed exceeded 6.5\%. The Hsiaolin landslide, one of the four giant landslides, was a deep-seated, dip-slope landslide that produced $2.7 \times 10^{7} \mathrm{~m}^{3}$ sediment volume (Wu et al. 2011). The sheer scale of this disaster was attributed to the extreme torrential rain, which

\footnotetext{
* Corresponding author

E-mail:ycchao@ncdr.nat.gov.tw
}

produced a record-breaking rainfall of $2361 \mathrm{~mm}$ in a mere 48 hours (Pan et al. 2011). The return period was over 200 years (Wu et al. 2011). Chiang and Chang (2011) documented that typhoons and rainfall rates are predicted to intensify as a result of climate change in the Western North Pacific. These meteorological changes will in turn trigger more active landslides in Taiwan. Additionally, Su et al. (2014) explored the typhoon rainfall event characteristics using dynamic downscaling climate change data. Their results showed that the typhoon rainfall duration in Taiwan will generally decrease, while the total rainfall amount will increase in the future. This is a direct warning that natural hazards, such as extreme rainfall, sediment events and flooding will become more frequent in the future.

Typhoon Morakot induced an obvious increase in sediment concentration and serious riverbed deposition in the Gaoping River, which severely disrupted the water supply in the Gaoping Weir. To prevent this from ever happening again, Taiwan's Water Resources Agency (WRA) has devoted substantial resources to study feasible water supply strategies for the Gaoping Weir reach (Yeh et al. 2011, 2012). Some research has focused on assessing the local 
levee arrangement, water level variations and channel migration under climate change conditions using the statistical downscaling method (Chang and Liu 2013; Lin et al. 2013). The statistical downscaling climate change data were estimated from historical weather observation records. Complex atmospheric and topographical indices and dynamic mechanisms were not considered. Therefore, this study applied dynamic downscaling climate change data, which considers the atmospheric index, to simulate the sediment transport processes in the Gaoping River watershed.

Numerous numerical models have been developed over the past few decades to simulate flow and sediment transport processes. These numerical models can be subdivided into three types: one-dimensional (1D), two-dimensional (2D), and three-dimensional (3D) models. For example, HEC-RAS is a 1D model widely used to calculate watersurface profiles and energy grade lines (USACE 2001). 2D and 3D numerical models were developed to simulate sedimentation in estuaries and harbours, river morphology, bridge pier scouring, and urban flooding, such as RMA2, FESWMS-2DH, CCHE2D/3D, SRH1D/2D, SOBEK, FLO-2D (Froehlich 1989; Norton et al. 1973; O'Brien et al. 1993; WL/Delft Hydraulics 1995; Jia and Wang 1999; Jia et al. 2005; Chao et al. 2013). The National Center for Computational Hydroscience and Engineering (NCCHE) at the University of Mississippi in the United States recently cooperated with Taiwan's WRA and National Chiao Tung University (NCTU) for CCHE2D/3D implementation in Taiwan. CCHE2D/3D showed satisfactory performance and stability on both experimental and field cases in Taiwan (Yeh and Wang 2009; Yeh 2014).

This study applied the CCHE2D model to simulate extreme sediment transport under a climate change scenario in the Gaoping River. The goals of this study are as follows: (1) use dynamic downscaling climate projection data to simulate sediment transport processes; (2) compare sediment yields between the late $20^{\text {th }}$ century and the late $21^{\text {st }}$ century; and (3) analyse the influences of different peak discharge on river bed changes.

\section{DESCRIPTION OF CCHE2D MODEL}

Developed by NCCHE, the CCHE2D model is a depthintegrated 2D hydrodynamic and sediment transport model for unsteady open channel flows. It can be used to evaluate steady and unsteady free surface flow, sediment transport, and morphological processes in natural rivers (Jia and Wang 1999). Brief descriptions of the hydrodynamic and sediment transport model are given below.

\subsection{Hydrodynamic Model}

The CCHE2D continuity and momentum equations can be expressed as (Jia and Wang 1999):

$$
\begin{aligned}
& \frac{\partial Z}{\partial t}+\frac{\partial(h u)}{\partial x}+\frac{\partial(h v)}{\partial y}=0 \\
& \frac{\partial u}{\partial t}+u \frac{\partial u}{\partial x}+v \frac{\partial u}{\partial y} \\
& =-g \frac{\partial Z}{\partial x}+\frac{1}{\rho h}\left(\frac{\partial h \tau_{x x}}{\partial x}+\frac{\partial h \tau_{x y}}{\partial y}\right)-\frac{\tau_{b x}}{\rho h}+f_{C o r} v \\
& \frac{\partial v}{\partial t}+u \frac{\partial v}{\partial x}+v \frac{\partial v}{\partial y} \\
& =-g \frac{\partial Z}{\partial y}+\frac{1}{\rho h}\left(\frac{\partial h \tau_{y x}}{\partial x}+\frac{\partial h \tau_{y y}}{\partial y}\right)-\frac{\tau_{b y}}{\rho h}+f_{C o r} u
\end{aligned}
$$

where $u$ and $v$ are the depth-integrated velocity components in the $x$ and $y$ directions, respectively; $g$ is the gravitational acceleration; $Z$ is the water surface elevation; $\rho$ is the water density; $h$ is the local water depth; $f_{\text {Cor }}$ is the Coriolis parameter; $\tau_{x x}, \tau_{x y}, \tau_{y x}$, and $\tau_{y y}$ are the depth integrated Reynolds stress; and $\tau_{b x}$ and $\tau_{b y}$ are the shear stresses on the bed surface.

\subsection{Sediment Transport Model}

The non-equilibrium sediment transport process simulations in the CCHE2D model are performed by solving the following equations ( $\mathrm{Wu} 2001$ ):

Suspended load:

$$
\begin{aligned}
& \frac{\partial\left(h C_{k}\right)}{\partial t}+\frac{\partial\left(u h C_{k}\right)}{\partial x}+\frac{\partial\left(v h C_{k}\right)}{\partial y} \\
& =\frac{\partial}{\partial x}\left(\varepsilon_{s} h \frac{\partial C_{k}}{\partial x}\right)+\frac{\partial}{\partial y}\left(\varepsilon_{s} h \frac{\partial C_{k}}{\partial y}\right)+\alpha \omega_{s k}\left(C_{*_{k}}-C_{k}\right)
\end{aligned}
$$

Bed load:

$$
\frac{\partial\left(\delta_{b} \dot{c}_{b k}\right)}{\partial t}+\frac{\partial\left(\alpha_{b x} q_{b k}\right)}{\partial x}+\frac{\partial\left(\alpha_{b y} q_{b k}\right)}{\partial y}+\frac{1}{L_{t}}\left(q_{b k}-q_{b * k}\right)=0
$$

Bed change:

$$
\left(1-p^{\prime}\right) \frac{\partial z_{b k}}{\partial t}=\alpha \omega_{s k}\left(C_{k}-C_{* k}\right)+\frac{1}{L_{t}}\left(q_{b k}-q_{b * k}\right)
$$

where $\varepsilon_{s}$ is the eddy diffusivity of sediment; $C_{k}$ is the concentration of the $k$-th size class of sediment; $C_{* k}$ is the corresponding transport capacity; $c_{b k}$ is the average concentration of bed load at the bed-load zone; $\alpha$ is the adaptation coefficient of suspended load; $\alpha_{b x}$ and $\alpha_{b y}$ are the direction cosines of bed load in the $x$ and $y$ directions; $\omega_{s k}$ is the sediment settling velocity; $q_{b^{* k}}$ and $q_{b k}$ are respectively the bed load transport capacity and transport rate; $\delta_{b}$ is the bed load layer thickness; $L_{t}$ is the adaptation length for bed load; $p^{\prime}$ is 
the porosity of bed material; and $\partial z_{b k} / \partial t$ is the bed change, due to size class $k$.

The non-equilibrium adaptation length $L_{t}$ characterizes the distance for sediment process adjustment from a nonequilibrium state into an equilibrium state, which is related to the sediment transport process, bed forms and channel geometry scales (Yeh et al. 2010).

\section{STUDY AND MODEL SETUP}

\subsection{Field Description}

The main river length and drainage area of the Gaoping River are $171 \mathrm{~km}$ and $3257 \mathrm{~km}^{2}$, respectively. The river has a relatively high average gradient of $1 / 150$. The Gaoping Watershed topography decreases gradually from northeast to southwest and the elevation undulates approximately $3900 \mathrm{~m}$. The topographic elevation, which exceeds $1000 \mathrm{~m}$, occupies $47 \%$ of the drainage area. Figure $1 \mathrm{~b}$ shows the computational domain ranging from downstream CS01 to the upstream CS74. It is approximately $36.3 \mathrm{~km}$ long and the average gradient is $1 / 1500$ in the study reach. The cross-section width in the computational domain is from $1491-3129 \mathrm{~m}$ and the mean width is $2197 \pm 346 \mathrm{~m}$.

The annual rainfall is between 1980 and $4350 \mathrm{~mm}$ in the Gaoping Watershed (WRA 2013). Over $90 \%$ of the annual rainfall $\left(\sim 3000 \mathrm{~mm} \mathrm{yr}^{-1}\right)$ in the Gaoping Watershed occurs in the wet season, between April and October. The high flow rate usually occurs in the summer, due to monsoon and typhoon activity (WRA 2013). The Central Moun- tain Range induces disproportionate spatial precipitation. Relatively heavy rainfall occurs especially in the mountain areas. The rainfall is less along the coastal areas and plains (Chu et al. 2011).

A gauge station called Lilin Bridge (1730H043) is located at cross section 71 (CS71) upstream of the study reach (Fig. 1). Based on the official management and planning report from the WRA, the 100-yr return period discharge, $\mathrm{Q}_{100}$, at the Liling Bridge gauge station is $30564 \mathrm{~m}^{3} \mathrm{~s}^{-1}$, and the $\mathrm{Q}_{2}, \mathrm{Q}_{5}$, and $\mathrm{Q}_{10}$ are 9666,15447 , and $19188 \mathrm{~m}^{3} \mathrm{~s}^{-1}$, respectively (WRA 2011). The particle diameter of $50 \%$ of the bed material, $\mathrm{D}_{50}$, slightly increased from $0.31-0.40 \mathrm{~mm}$ during 2007 - 2012 (WRA 2011).

\subsection{Selection of Extreme Typhoon Events Under Climate Change Scenario}

Since statistical downscaling techniques are unable to describe the typhoon event process. This study used dynamic downscaling projection data to try to depict the full hydrography of a typhoon event. The dynamic downscaling projection data were produced by the Taiwan Climate Change Projection and Information Platform (TCCIP) project. The TCCIP project introduced a dynamic downscaling dataset from the Meteorological Research Institute (MRI) that was further downscaled into $5 \mathrm{~km}$ grids using the Weather Research and Forecasting modeling system (WRF) (MOST 2014). A balance across all sources (A1B emission scenario) was used to evaluate the environmental variations
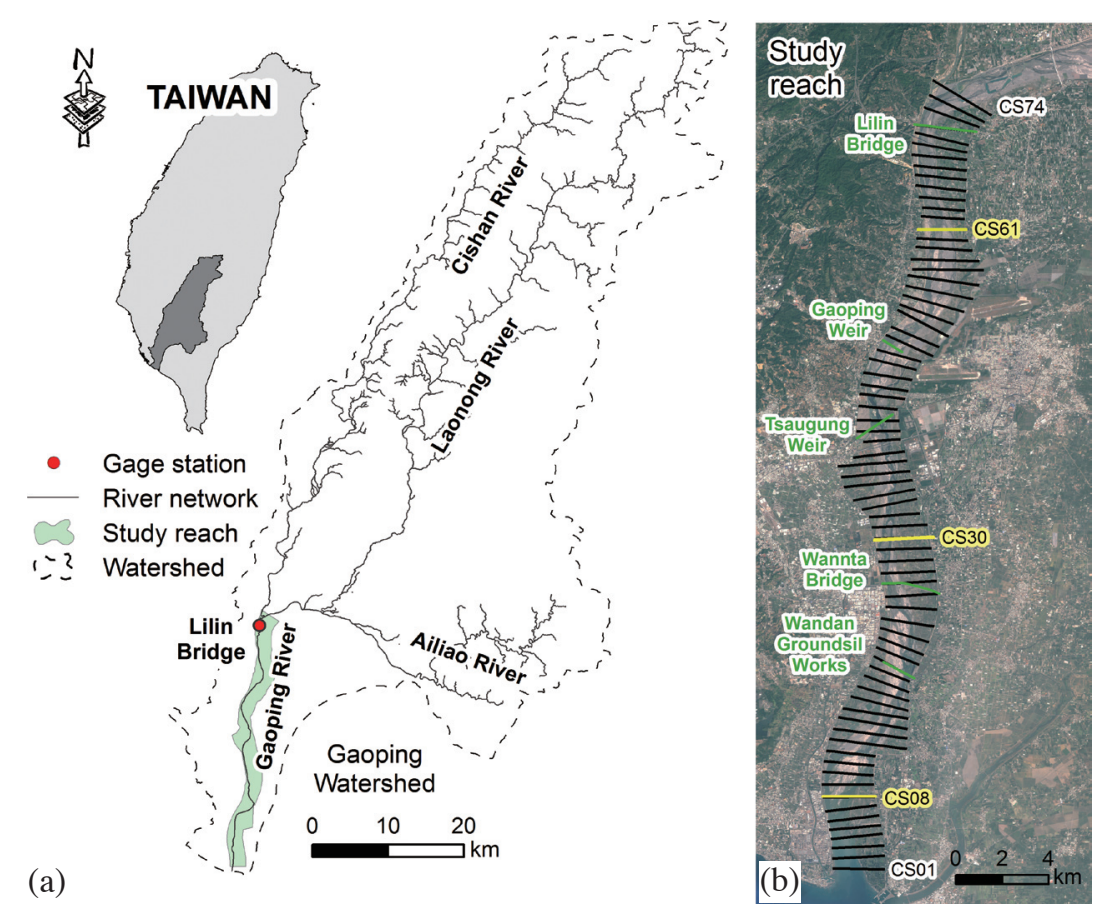

Fig. 1. Gaoping Watershed, Taiwan, (a) location of study reach and gauge station; (b) aerial photo of the study reach from CS01 to CS74 (estuary to the confluence at Cishan River and Laonong River). CS08, CS30, and CS61 are the cross-sections for calibration and validation. 
in the future.

Figure 2 shows the mean total cumulative rainfall distribution within the top ten grades of typhoon events, which identifies that the typhoon center is within $300 \mathrm{~km}$ from the coast of Taiwan during the late $20^{\text {th }}$ century (1979 to $2003-y r$ ) and late $21^{\text {st }}$ century (2075 to 2099-yr). This is an evident warning that the rainfall intensity will increase in the late $21^{\text {st }}$ century, especially in the central and southern parts of Taiwan ( $\mathrm{Su}$ et al. 2014). We used the maximum 24-hour cumulative rainfall to sort the typhoon events under the climate change scenario to model the climate change rainfall characteristics.

The maximum late $20^{\text {th }}$ century and late $21^{\text {st }}$ century 24 hour cumulative rainfall and duration rankings from one to ten are shown in Fig. 3a. The mean maximum 24-hour cumulative late $20^{\text {th }}$ century and late $21^{\text {st }}$ century rainfall are
534 and $917 \mathrm{~mm}$, respectively. The mean rainfall durations are 52 and 48 hours for the late $20^{\text {th }}$ century and late $21^{\text {st }}$ century. The late $21^{\text {st }}$ century rainfall obviously exhibits a short duration with high intensity. In order to isolate the climate change rainfall characteristics, this study selected the first ranked data to simulate the extreme rainfall events. Figure $3 b$ shows the first ranked rainfall and cumulative rainfall hyetographs for the late $20^{\text {th }}$ century and late $21^{\text {st }}$ century period. The mean rainfall intensities are 15.74 and $33.45 \mathrm{~mm} \mathrm{hr}^{-1}$, respectively. The late $20^{\text {th }}$ century and late $21^{\text {st }}$ century rainfall durations are 120 and 48 hours, respectively.

\subsection{Initial Conditions and Boundary Conditions}

The initial computational mesh bed elevations were interpolated and obtained using cross-sectional data from
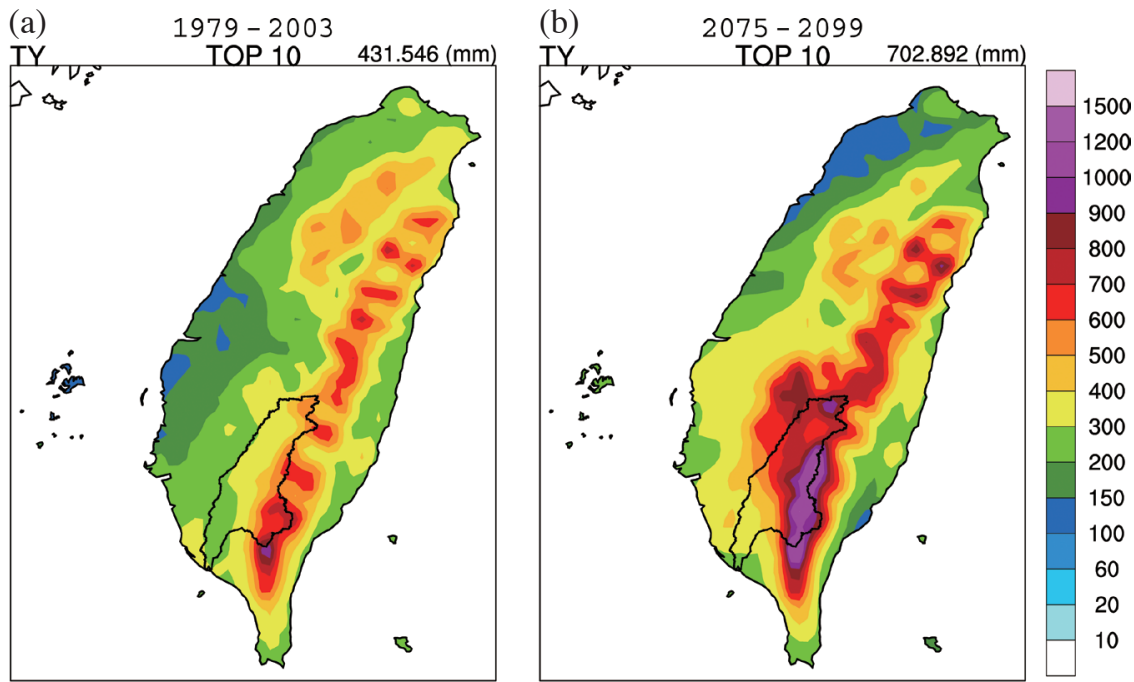

Fig. 2. Average cumulative rainfall (mm) under climate change scenario within the top ten grades of extreme rainfall, (a) and (b) represent the late $20^{\text {th }}$ century and late $21^{\text {st }}$ century periods, respectively.

(a)

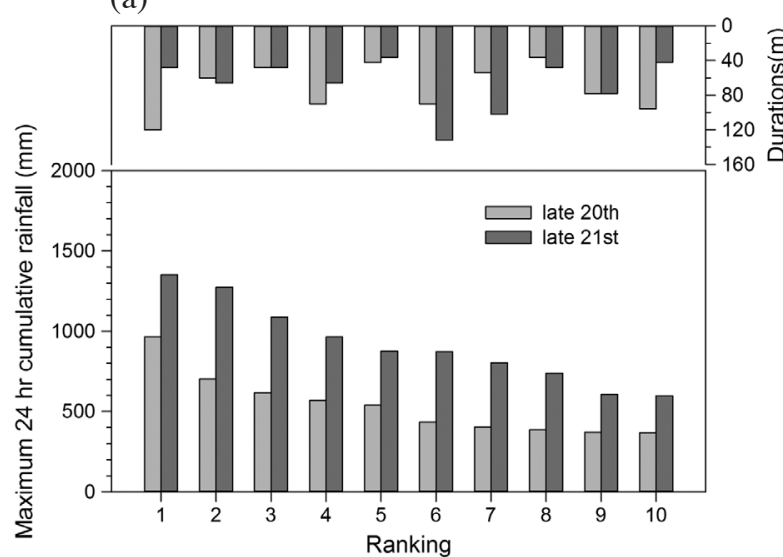

(b)

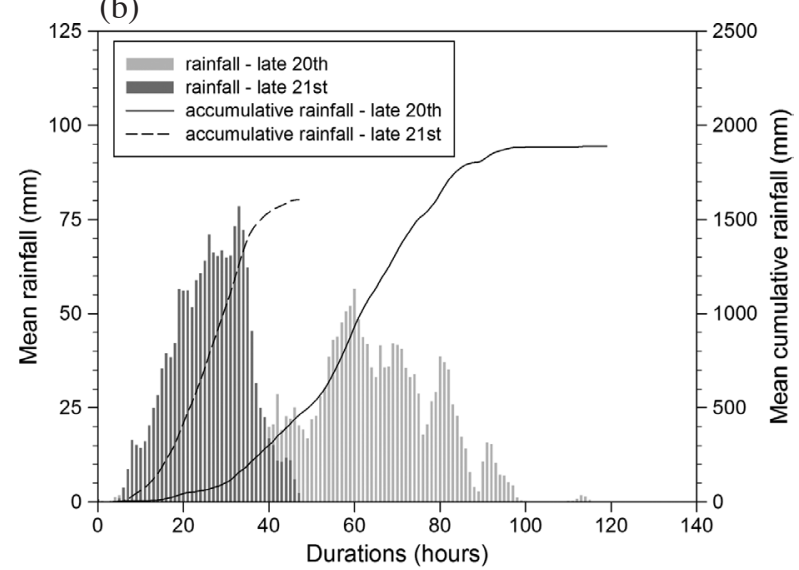

Fig. 3. Ranking of rainfall events from one to ten for the late $20^{\text {th }}$ century and late $21^{\text {st }}$ century; (a) shows sorting of maximum 24 -hour cumulative rainfall and its durations; (b) illustrates the mean rainfall and mean cumulative rainfall for ranking rainfall events. 
2008 and 2012. The 2010 cross-sectional data were used for 2008 data model calibrations. The 2013 data were used for the 2012 data model validations. This study employed 2013 cross-sectional data in assuming the initial bed under a climate change scenario.

The bed materials were obtained from the official management and planning report (WRA 2011). Sediment size classes ranging from $0.0625-11.71$ and $0.0625-1.52 \mathrm{~mm}$ were selected to compute the associated sediment transport in model calibration and validation, respectively. The sediment transport capacity and bed roughness were determined using two formulas - one from Wu et al. (2000) and the other from Van Rijn's (1984). The adaptation length, factor, and mixing layer thickness were $8000,0.25$, and $0.25 \mathrm{~m}$, respectively. These factors were evaluated by Yeh et al. (2012).

The CCHE2D model was applied to simulate the extreme flooding that induces intense morphological changes under a climate change scenario in the Gaoping River. The most severe typhoon events during the 2008 - 2010 and 2012 - 2013 periods were Typhoon Morakot and Typhoon Saola, respectively. Therefore, these two typhoon events were selected for model calibration and validation. The complete hydrograph for Typhoon Morakot was selected from 5 to 10 August 2009, and the total simulated time was 250 hours in the model calibration. Typhoon Saola was used as the simulated period for validation, which was between 1 to 5 August 2012, reaching a total of 119 hours. Figures $4 a$ and b show the flow and sediment hydrographs of significant flood events at the upstream boundary for model calibration and validation. The inflow hydrograph at the upstream was obtained from the Lilin Bridge gauge station. The sediment concentration was evaluated using a rating curve obtained from the measured suspended load data (WRA 2009, 2012). The downstream water stage hydrographs were assessed from the FVCOM storm surge model (NCDR 2015), which is shown in Figs. $4 \mathrm{c}$ and d.

The climate change scenario simulations used the cross-sectional data from 2013 as the initial bed elevation. The sediment transport conditions followed the model calibration and validation results. The inflow hydrograph and outflow water stage data were obtained from the TCCIP and NCDR (National Science and Technology Center for Disaster Reduction) technical report results (MOST 2014; NCDR 2015), which are shown in Fig. 5. The outlet water stage hydrographs were retrieved from the FVCOM storm surge model results (NCDR 2015).

\section{RESULTS AND DISCUSSIONS}

\subsection{Model Calibration and Validation}

Figure 6 shows the bed elevation thalwegs and bed changes. The bed changes are the bed elevation variation in thalwegs. The positive and negative bed change values represent bed aggradation and degradation relative to the initial bed elevation. As depicted in Fig. 6, obvious excessive aggradation occurred from the Wannta Bridge to the Gaoping Weir reach, with significant degradation near the estuary in the model calibration. In the model validation, a slightly higher aggradation occurred from the Wannta Bridge to the Gaoping Weir reach. In general, the model matched closely with the measured values.

Figure 7 shows a comparison of the simulated and measured cross-sectional data in the study reach. Some deviations occur in the calibration case. The calculated lateral erosion in some cross-sections does not agree well with the measured data, e.g., in Figs. 7a and c. Moreover, some cross-sections are slightly over-estimated in terms of the deposition, e.g., in Fig. 7e. On the other hand, the bed changes in the cross-sections are generally in line with the measurements in the validation case.

The deviation in the calibration case may be caused by the limitations of performing lateral migration mechanisms in the present model, and the complex morphology in the estuary zone was not considered. In addition, 27 typhoons affected Taiwan from 2009 - 2013. Meanwhile, the WRA implemented dredging after the typhoons, which induces obvious deviation in the simulated and measured results. Overall, the simulated results in the calibration and validation basically exhibit good agreement with the measured data. Therefore, this model and its relevant parameters can be used in the following simulations.

\subsection{Simulation Results and Discussions for the Scenario of Climate Change}

Figure 8 shows the water levels (WL) and their corresponding bed profiles at peak discharge $\left(\mathrm{Q}_{\mathrm{p}}\right)$ in the late $20^{\text {th }}$ century and late $21^{\text {st }}$ century periods. The mean water level in the late $21^{\text {st }}$ century is $1.11 \pm 0.31 \mathrm{~m}$ relatively higher than the late $20^{\text {th }}$ century at peak flow discharge. There is more severe degradation in the late $21^{\text {st }}$ century than in the late $20^{\text {th }}$ century at peak flow discharge, and the mean degraded depth relatively increases $0.30 \pm 0.29 \mathrm{~m}$. The extreme high water level indicates high potential risk for overbank disasters between the Tsaugung Weir and Liling Bridge reach. There will be obvious scour around the Wannta Bridge at peak discharge under the climate change scenario. Increasing the embankment levels and bridge pier protection will definitely be needed to avoid future disasters.

Figure 9 shows the simulated sediment aggradation results under the climate change scenario. The dashed lines indicate the initial bed, the solid lines show the simulated results for the late $20^{\text {th }}$ century, and the circle-solid lines show the simulated results for the late $21^{\text {st }}$ century. The average depositions for the late $20^{\text {th }}$ century and late $21^{\text {st }}$ century are $3.31 \pm 1.61$ and $2.68 \pm 1.20 \mathrm{~m}$. Although the sediment aggradation is $19 \%$ less in the late $21^{\text {st }}$ century than the late $20^{\text {th }}$ century, the simulated results reveal that the aggradation is 
more severe toward the upstream in both periods, and the highest aggradation is at the Liling Bridge and downstream of the Tsaugung Weir, as shown in Fig. 9a. Figures 9b - d depict the cross-sectional bed elevation profile changes at CS08, CS30, and CS61. The Gaoping Weir is considered the water resource pivot in southern Taiwan. Located between the Liling Bridge and Tsaugung Weir, this exactly falls within the severe aggradation reach. Hence, the aggradation may cause public water supply problems in southern Taiwan in the future.
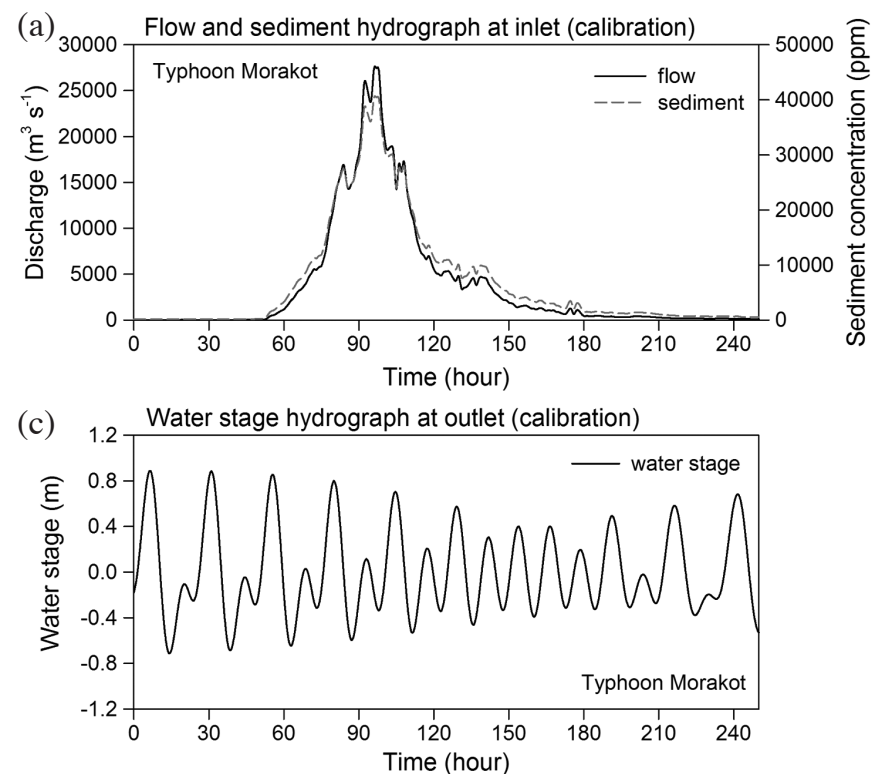

Figure 10 shows the simulated results for mean bed changes and cumulated sedimentation under the climate change scenario. The mean bed changes and the averaged bed elevation variation in each cross-section are used to present the sediment variations to avoid possible overestimation in calculating sediment degradation and aggradation in thalwegs using bed changes. The mean bed change values are $1.86 \pm 0.89 \mathrm{~m}$ in the late $20^{\text {th }}$ century and $1.59 \pm 0.73 \mathrm{~m}$ in the late $21^{\text {st }}$ century. The sediment variations and cumulated volumetric changes are illustrated according to the mean bed

Fig. 4. Inlet (upstream) and outlet (downstream) boundary conditions for model calibration and validation; (a) and (c) show flow conditions of Typhoon Morakot for model calibration, (b) and (d) show flow conditions of Typhoon Saola for model validation.
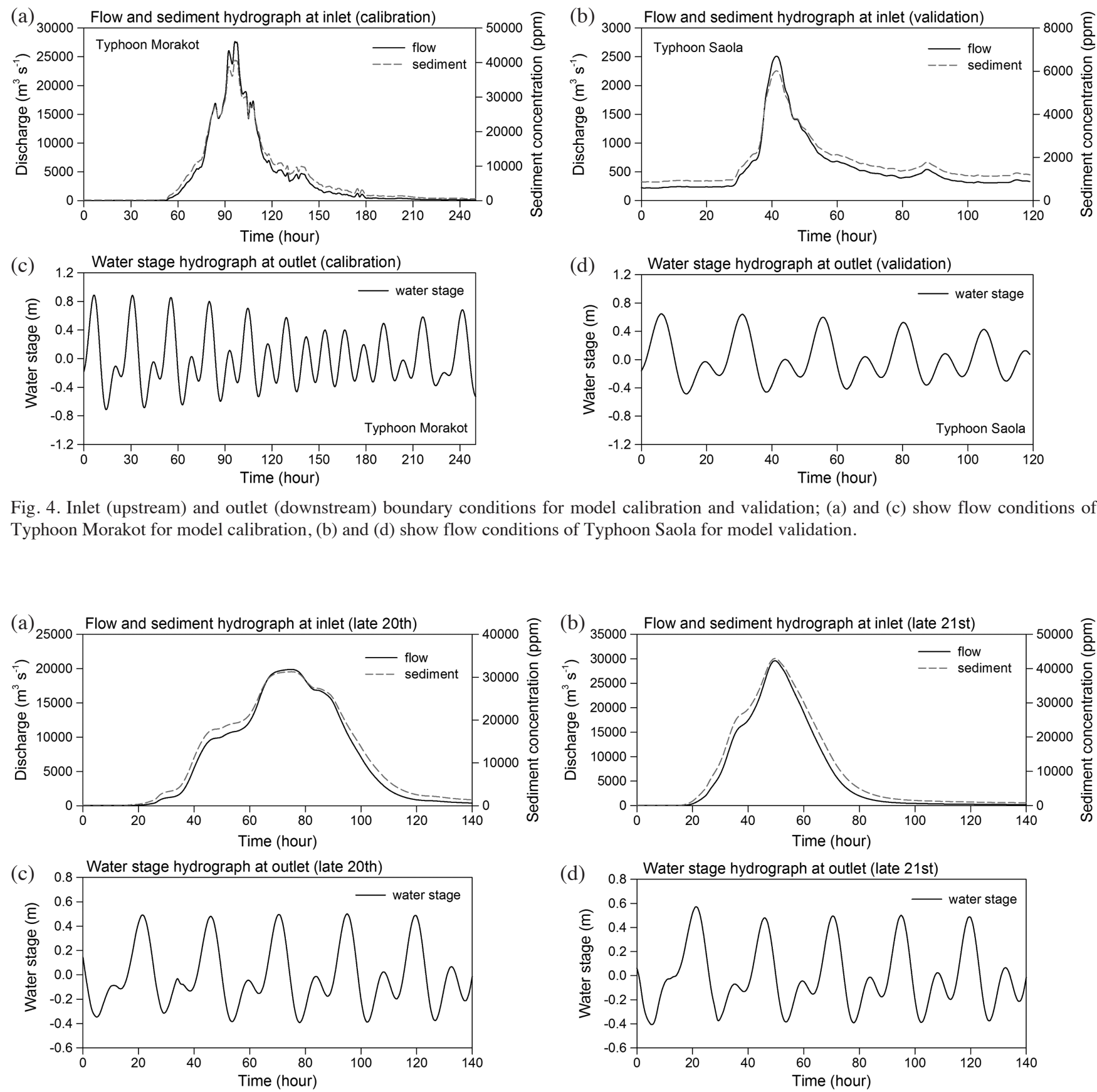

Fig. 5. Inlet (upstream) and outlet (downstream) boundary conditions for the extreme flooding event in climate change scenario; (a) and (c) for the late $20^{\text {th }}$ century, (b) and (f) for the late $21^{\text {st }}$ century. 
(a) Calibration
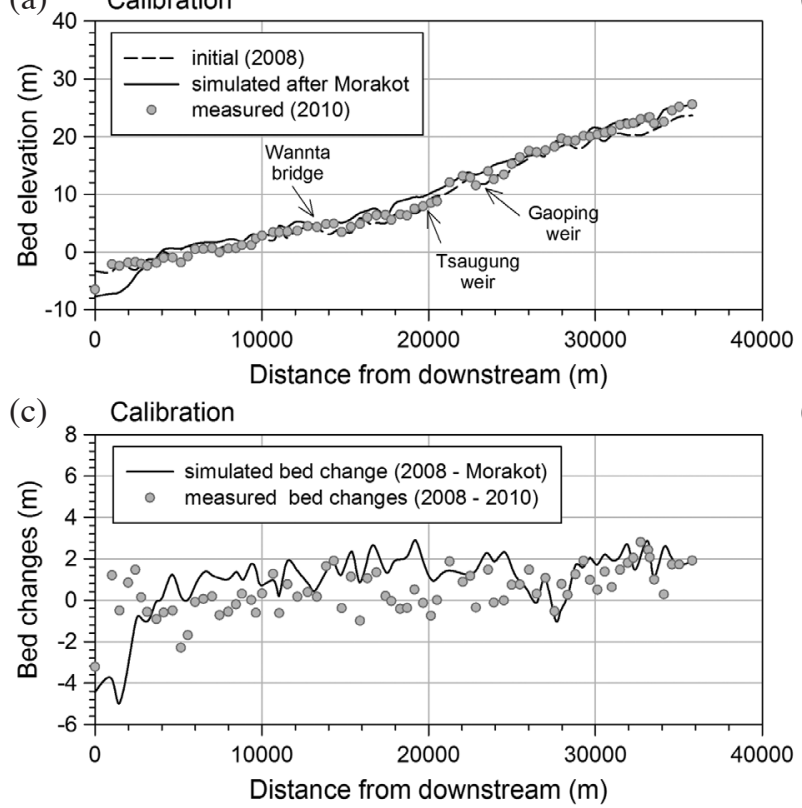

(b) Validation

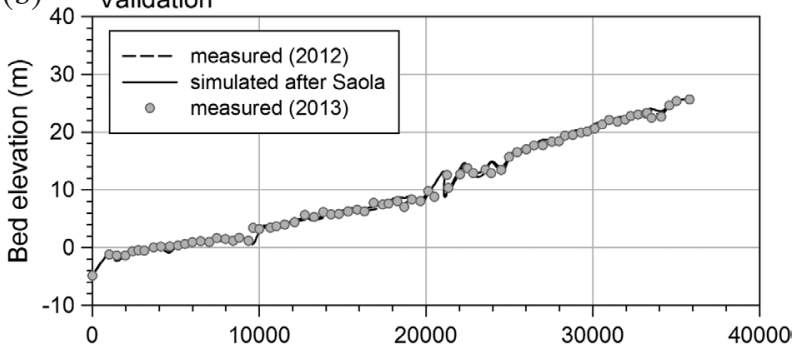

Distance from downstream $(\mathrm{m})$

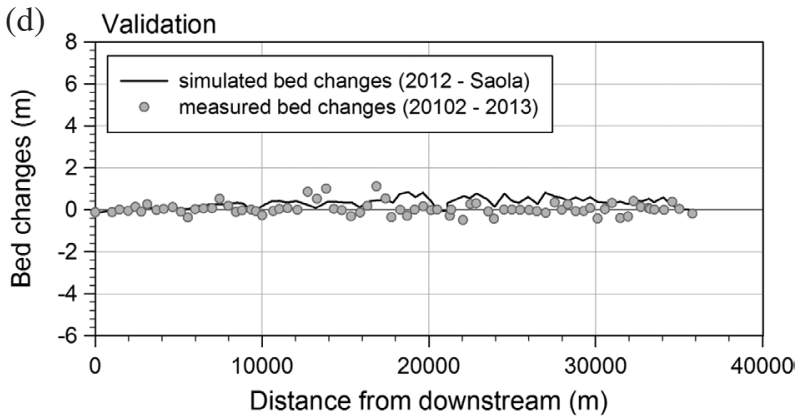

Fig. 6. Simulated and measured thalwegs and bed changes; (a) and (c) for model calibration, (b) and (d) for model validation.
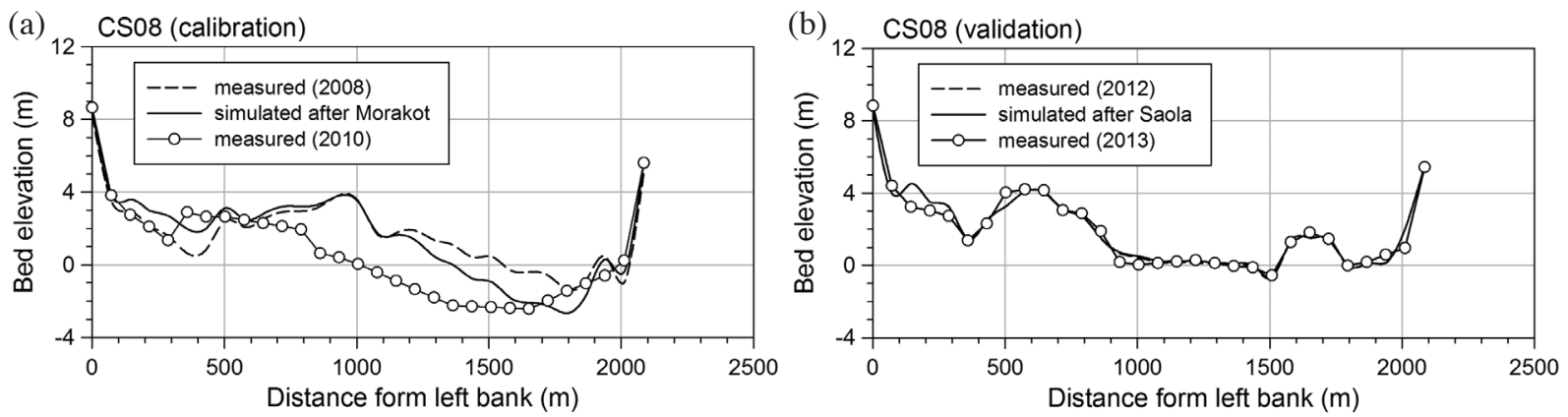

(c) $\operatorname{CS} 30$ (calibration)

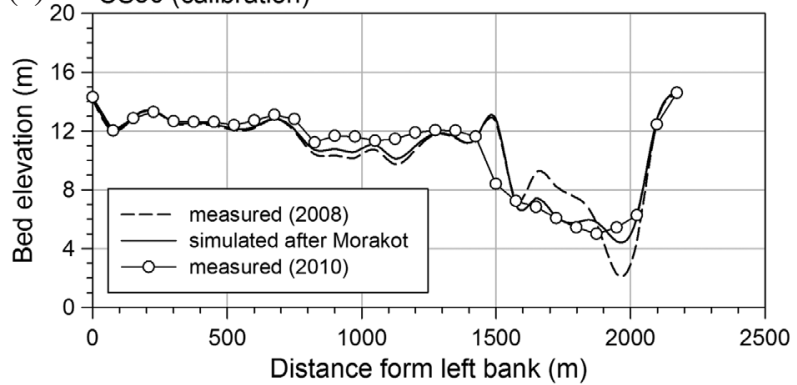

(d) $\operatorname{CS} 30$ (validation)
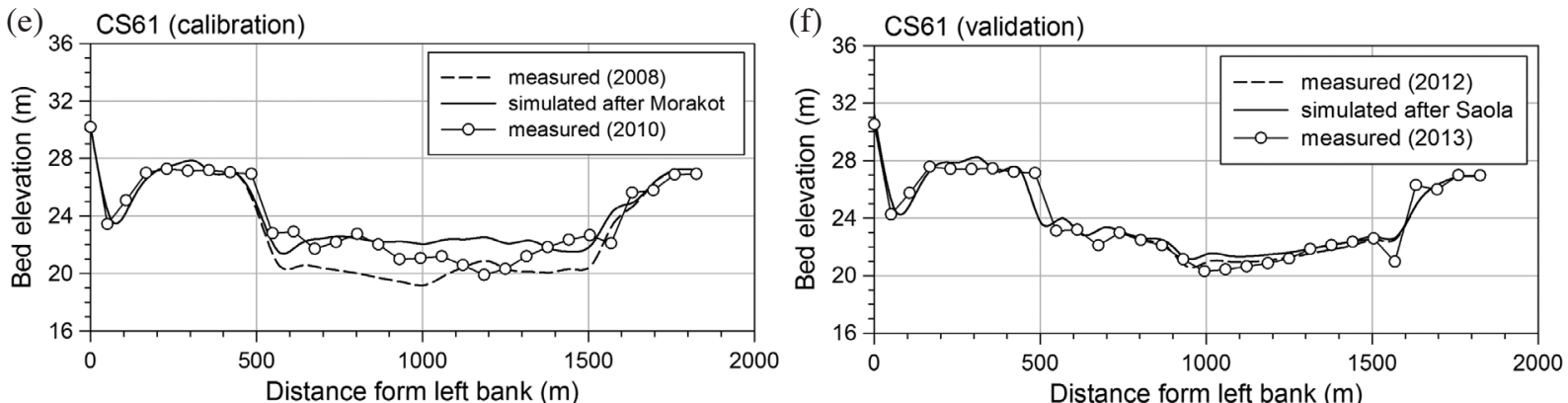

Fig. 7. Comparison of simulated and measured cross-sectional bed profiles; (a), (c), (e) for model calibration; (b), (d), (f) for model validation. 


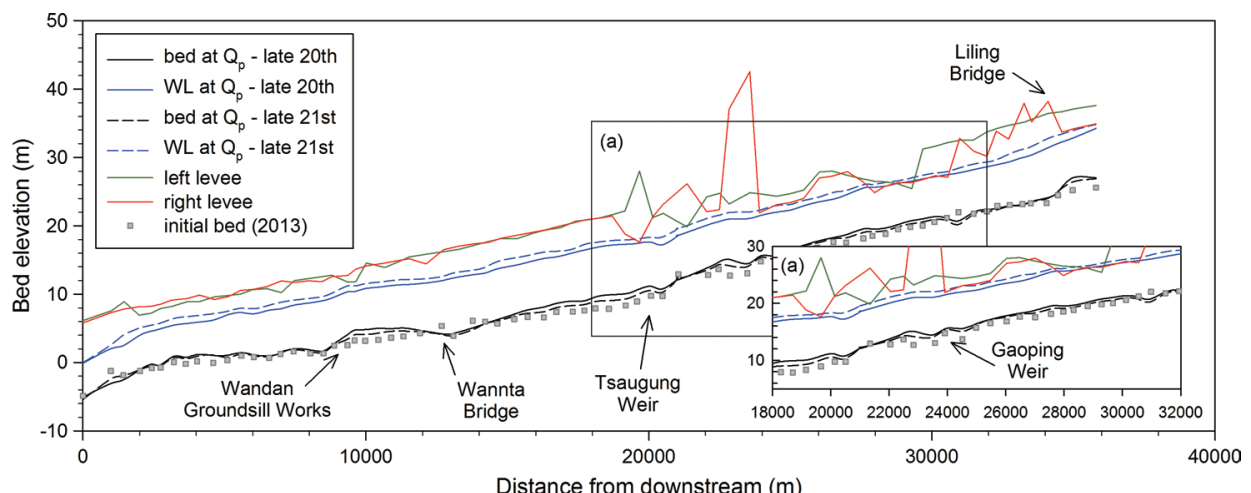

Fig. 8. The highest water levels and their corresponding thalwegs at peak discharges in the late $20^{\text {th }}$ century and late $21^{\text {st }}$ century.
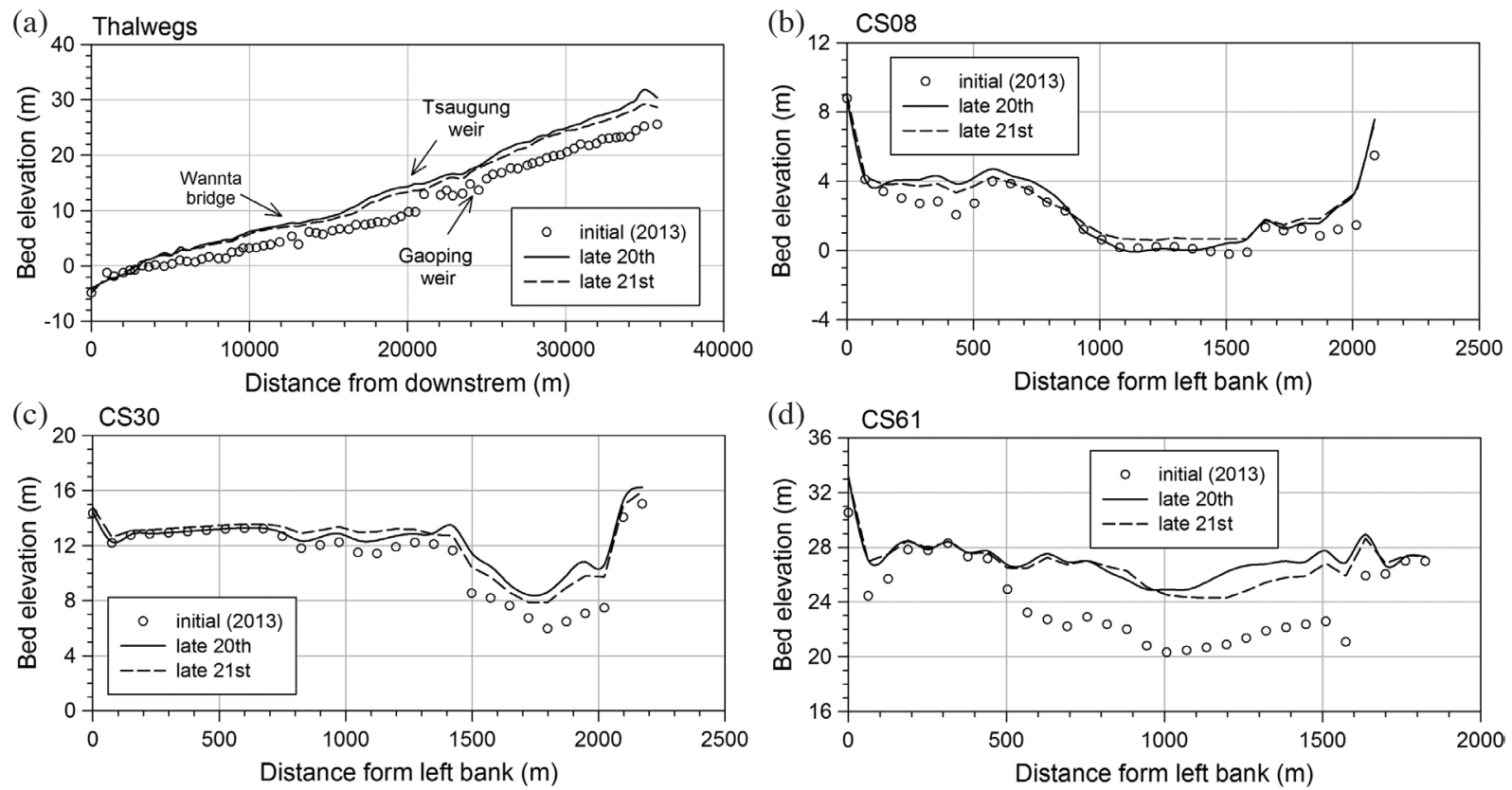

Fig. 9. Simulated results under climate change scenario; (a) shows bed elevation thalwegs; (b), (c), (d) depict the cross-sectional profiles of bed changes.

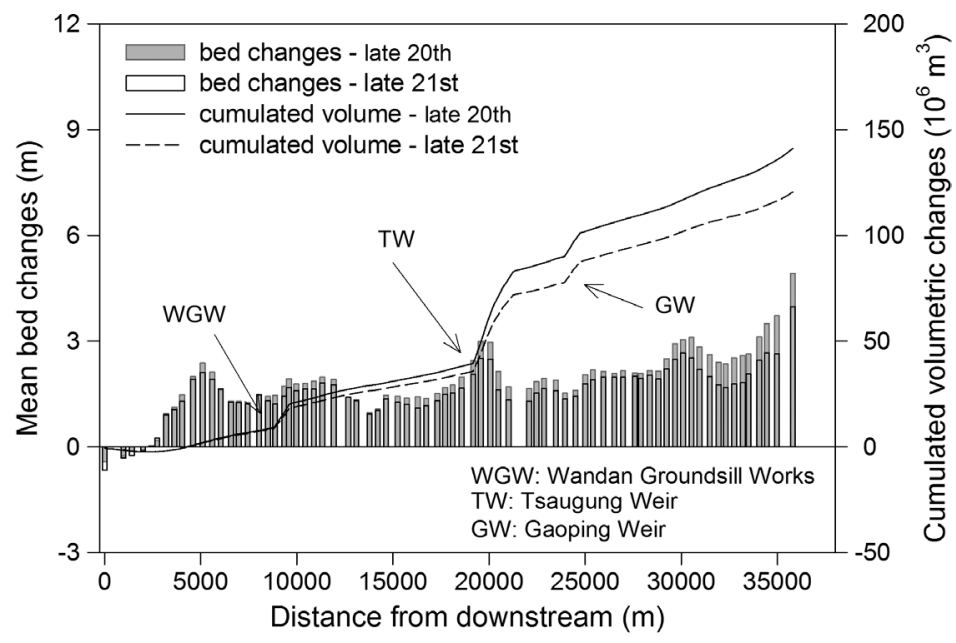

Fig. 10. Longitudinal profiles of mean bed changes and accumulated deposition. 
changes and channel widths in the entire Gaoping River. The sediment degradation and aggradation are shown in the longitudinal profile. As the cumulated volumetric changes considered the contribution from channel widths, it could explain why the mean bed changes do not agree with the accumulated volumetric changes. The sediment variation in the late $20^{\text {th }}$ century is $141.11 \times 10^{6} \mathrm{~m}^{3}$, while the sediment variation in the late $21^{\text {st }}$ century is reduced by $15 \%$ compared to the late $20^{\text {th }}$ century. Furthermore, there are three obvious knickpoints where the Gaoping River sediment rapidly accumulates in both the late $20^{\text {th }}$ century and late $21^{\text {st }}$ century. Landemaine et al. (2015) stated that artificial river structures, such as weirs and dams, could modify the river morphology and induce changes in the sediment transport capacity. Wandan Groundsill Works, Tsaugung Weir and the Gaoping Weir therefore play major roles in the Gaoping River sedimentation.

To further understand why the sediment aggradation is less in the late $21^{\text {st }}$ century than in the late $20^{\text {th }}$ century, this study used the experimental design concept to reduce the variables and explore the relationship between the hydrograph and sediment deposition at different peak flow discharges. We reduced 25 and $50 \%$ of extreme flood event discharges in both the late $20^{\text {th }}$ century and late $21^{\text {st }}$ century to simulate and evaluate the sediment aggradation with the same flood durations (Fig. 11a).

Figure 11 shows the six hydrographs with the same flood durations and their relationship to the bed changes and peak discharges. The range of bed change is from $3.31 \pm 1.61$ to $0.07 \pm 0.67 \mathrm{~m}$, and the range of mean bed change is from $1.86 \pm 0.89$ to $0.02 \pm 0.16 \mathrm{~m}$ in six hydrographs, as shown in Table 1. An interesting result was found in Fig. 11b. When peak flow discharges reach a critical discharge, which is the $\mathrm{Q}_{10}\left(19188 \mathrm{~m}^{3} \mathrm{~s}^{-1}\right)$ in the Gaoping River for this case, significant and abrupt bed changes will occur. However, these bed changes will gradually slow down when peak discharge increases, as shown in the gray box in Fig. 11b. Although the bed changes are still considered significant compared to those flood peak discharge smaller than $\mathrm{Q}_{10}$, it is a significant fact that the bed changes are not as abrupt as in the $\mathrm{Q}_{10}$ discharge. These simulation results could help explain why the aggregation in the late $20^{\text {th }}$ century is more severe than in the late $21^{\text {st }}$ century. In addition, we quantified the simulation results and defined a bed change ratio (BCR) index to better understand the riverbed change variations from a peak discharge value in a flood event. The index is a ratio of bed changes and mean bed changes, which has a negative correlation with the peak flow discharges.
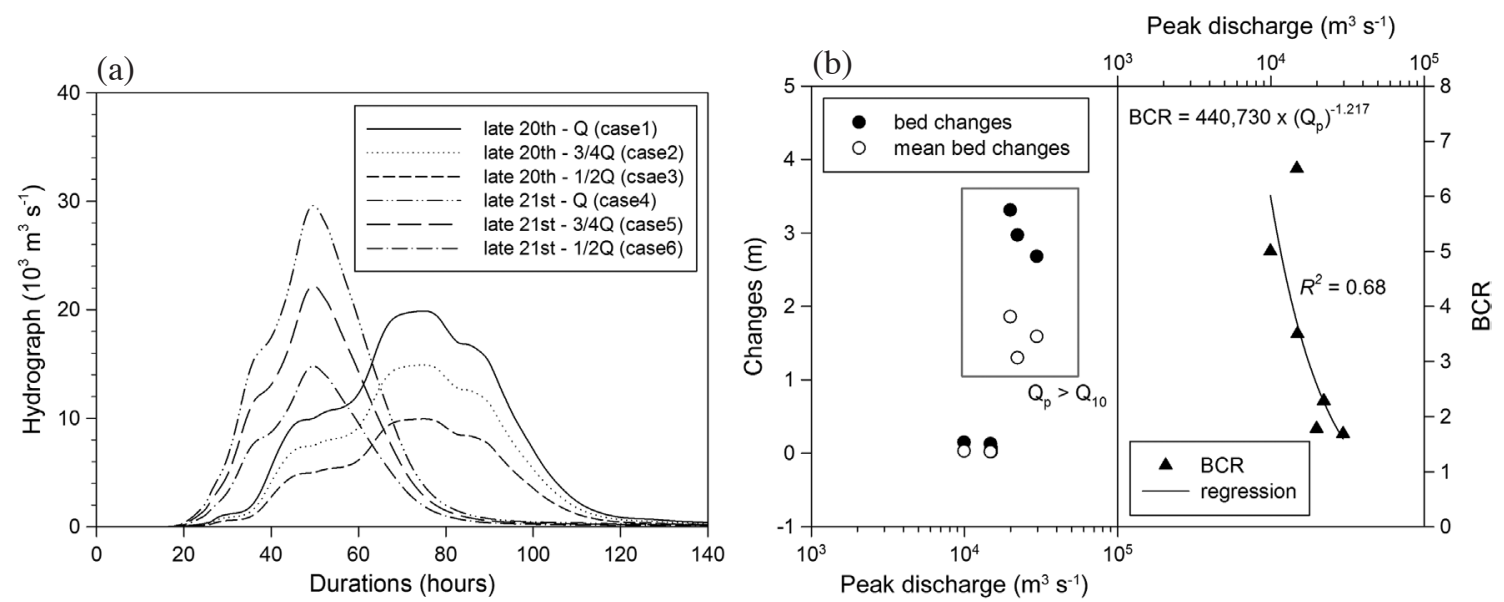

Fig. 11. Different hydrographs and bed change results for the Gaoping River; (a) shows different discharge hydrographs for the same duration with different rainfall intensity, (b) depicts relationship between peak discharge with changes and BCR (BCR is a ratio of bed changes and mean bed changes).

Table 1. Simulation results for different hydrographs; asterisk indicates mean \pm standard deviation.

\begin{tabular}{c|ccc|ccc}
\hline & \multicolumn{3}{|c|}{ late 20 $\mathbf{2}^{\text {th }}$ century } & \multicolumn{3}{c}{ late 21 ${ }^{\text {st }}$ cnetury } \\
\cline { 2 - 7 } & $\mathbf{Q}$ & $\mathbf{0 . 7 5}$ & $\mathbf{0 . 5 Q}$ & $\mathbf{Q}$ & $\mathbf{0 . 7 5 Q}$ & $\mathbf{0 . 5 Q}$ \\
\cline { 2 - 7 } & Case1 & Case2 & Case3 & Case4 & Case5 & Case6 \\
\hline $\mathrm{Q}_{\mathrm{p}}\left(\mathrm{m}^{3} \mathrm{~s}^{-1}\right)$ & 19888 & 14916 & 9944 & 29572 & 22179 & 14786 \\
Bed changes $(\mathrm{m})^{*}$ & $3.31 \pm 1.61$ & $0.07 \pm 0.67$ & $0.15 \pm 0.38$ & $2.68 \pm 1.20$ & $2.97 \pm 1.27$ & $0.13 \pm 0.39$ \\
Mean bed changes $(\mathrm{m})^{*}$ & $1.86 \pm 0.89$ & $0.02 \pm 0.23$ & $0.03 \pm 0.12$ & $1.59 \pm 0.73$ & $1.30 \pm 0.58$ & $0.02 \pm 0.16$ \\
\hline
\end{tabular}




\section{CONCLUSION}

This study employed dynamic downscaling climate projection data to understand the sediment transport processes in future extreme typhoon events. According to the climate projection data, the runoff peak discharge in the late $21^{\text {st }}$ century will be 1.48 times larger than in the late $20^{\text {th }}$ century. However, the sediment aggradation volume in the late $21^{\text {st }}$ century will be $15 \%$ less than the late $20^{\text {th }}$ century. To explain this outcome, this study applied the experimental design method and found that severe riverbed changes had a negative correlation with the peak discharge in extreme floods. This could help delineate why the aggregation in the late $20^{\text {th }}$ century was more severe than in the late $21^{\text {st }}$ century. It should be noted that this study only applied a single model of climate projection data. Uncertainties in the simulation results were inevitable. For future research, more climate model projections should be considered to reduce the uncertainties from climate models.

Acknowledgements The authors would also like to thank the Ministry of Science and Technology, Taiwan (MOST) for financially supporting this research under Contract No. MOST103-2621-M-865-001.

\section{REFERENCES}

Chang, C. E. and W. C. Liu, 2013: Modeling runoff discharge in the Kaoping River catchment under climate change. Taiwan Water Conservancy, 61, 41-59.

Chao, X., A. K. M. A. Hossain, and Y. Jia, 2013: Three dimensional numerical modeling of flow and pollutant transport in a flooding area of 2008 US Midwest Flood. Am. J. Clim. Change, 2, 116-127, doi: 10.4236/ ajcc.2013.22012. [Link]

Chiang, S. H. and K. T. Chang, 2011: The potential impact of climate change on typhoon-triggered landslides in Taiwan, 2010-2099. Geomorphology, 133, 143-151, doi: 10.1016/j.geomorph.2010.12.028. [Link]

Chu, H. J., T. Y. Pan, and J. J. Liou, 2011: Extreme precipitation estimation with Typhoon Morakot using frequency and spatial analysis. Terr. Atmos. Ocean. Sci., 22, 549558, doi: 10.3319/TAO.2011.05.10.02(TM). [Link]

Froehlich, D. C., 1989: HW031.D - Finite element surfacewater modeling system: Two-dimensional flow in a horizontal plane. Users Manual, Federal Highway Administration Report FHWA-RD-88-177, U.S. Geological Survey, $285 \mathrm{pp}$.

Jia, Y. and S. S. Y. Wang, 1999: Numerical model for channel flow and morphological change studies. J. Hydraul. Eng., 125, 924-933, doi: 10.1061/(ASCE)07339429(1999)125:9(924). [Link]

Jia, Y., S. Scott, Y. Xu, S. Huang, and S. S. Y. Wang, 2005: Three-dimensional numerical simulation and analysis of flows around a submerged weir in a channel bendway. J. Hydraul. Eng., 131, 682-693, doi: 10.1061/ (ASCE)0733-9429(2005)131:8(682). [Link]

Landemaine, V., A. Gay, O. Cerdan, S. Salvador-Blanes, and S. Rodrigues, 2015: Morphological evolution of a rural headwater stream after channelisation. Geomorphology, 230, 125-137, doi: 10.1016/j.geomorph.2014.11.011. [Link]

Lin, Y. J., J. S. Lai, W. C. Liu, Y. C. Tan, and T. J. Chang, 2013: A Study of Renewal of Adaptation for Flood and Sediment Mitigation due to Climate Change of Kaoping River, MOEAWRA1020201, Water Resources Planning Institute, WRA, Taiwan.

MOST (Ministry of Science and Technology), 2010: Disaster Survey and Analysis of Morakot Typhoon, Ministry of Science and Technology, Taipei, Taiwan.

MOST (Ministry of Science and Technology), 2014: Taiwan Climate Change Projection and Information Platform, NSC102-2621-M-492-001, Ministry of Science and Technology, Taipei, Taiwan.

NCDR (National Science and Technology Center for Disaster Reduction), 2015: The Basin-Wide Disaster Impact Assessments under Extreme Typhoon Event of Climate Change in Kao-Ping River Basin, NCDR103T18, National Science and Technology Center for Disaster Reduction.

Norton, W. R., I. P. King, and G. T. Orlob, 1973: A Finite Element Model for Lower Granite Reservoir, Water Resources Engineers, Inc., Walnut Creek, California, $286 \mathrm{pp}$.

O'Brien, J. S., P. Y. Julien, and W. T. Fullerton, 1993: Two-dimensional water flood and mudflow simulation. J. Hydraul. Eng., 119, 244-261, doi: 10.1061/ (ASCE)0733-9429(1993)119:2(244). [Link]

Pan, T. Y., Y. T. Yang, H. C. Kuo, Y. C. Tan, J. S. Lai, T. J. Chang, C. S. Lee, and K. H. Hsu, 2011: Improvement of statistical typhoon rainfall forecasting with ANN-based southwest monsoon enhancement. Terr. Atmos. Ocean. Sci., 22, 633-645, doi: 10.3319/ TAO.2011.07.04.01(TM). [Link]

Su, Y. F., J. J. Liou, C. T. Cheng, and A. Kitoh, 2014: Assessment of the change of typhoon rainfall event characteristics using dynamic downscaling data under a climate change scenario. J. Taiwan Agric. Eng., 60, 48-60.

USACE, 2001: River Analysis System HEC-RAS, Hydraulic Reference Manual version 3.0, Hydrologic Engineering Center.

Van Rijn, L. C., 1984: Sediment transport, Part III: Bed forms and alluvial roughness. J. Hydraul. Eng., 110, 1733-1754, doi: 10.1061/(ASCE)07339429(1984)110:12(1733). [Link]

WL/Delft Hydraulics, 1995: SOBEK 1.0: User's Guide, Delft, The Netherlands. 
WRA (Water Resource Agency), 2009: Hydrological Year Book of Taiwan Republic of China 2009, Water Resource Agency, Ministry of Economic Affairs, Taiwan.

WRA (Water Resource Agency), 2011: Integrated Regulation Planning of Kao-Ping River Basin (2/2), The Seventh River Management Office, Water Resources Agency, Ministry of Economic Affairs.

WRA (Water Resource Agency), 2012: Hydrological Year Book of Taiwan, Water Resource Agency, Ministry of Economic Affairs, Taiwan.

WRA (Water Resource Agency), 2013: A Study of Renewal of Adaptation for Flood and Sediment Mitigation due to Climate Change of Kaoping River, MOEAWRA1020201, Water Resources Planning Institute, Water Resources Agency, Ministry of Economic Affairs, Taiwan.

Wu, C. H., S. C. Chen, and H. T. Chou, 2011: Geomorphologic characteristics of catastrophic landslides during typhoon Morakot in the Kaoping Watershed, Taiwan. Eng. Geol., 123, 13-21, doi: 10.1016/j. enggeo.2011.04.018. [Link]

Wu, W., 2001: CCHE2D sediment transport model (version 2.1). National Center for Computational Hydroscience and Engineering, The University of Mississippi , MS, USA.

Wu, W., W. Rodi, and T. Wenka, 2000: 3D numerical modeling of flow and sediment transport in open channels.
J.Hydraul.Eng., 126, 4-15, doi: 10.1061/(ASCE)07339429(2000)126:1(4). [Link]

Yeh, K. C., 2014: Implement and Application Study of CCHE3D Mobile-bed Model (1/3), MOEAWRA1020120, Water Resources Planning Institute, Water Resources Agency, Taiwan.

Yeh, K. C. and S. S. Y. Wang, 2009: Implement and Application Study of NCCHE's River Migration Models, Water Resources Planning Institute, Water Resources Agency, Taiwan.

Yeh, K. C., S. S. Y. Wang, H. Chen, C. T. Liao, Y. Jia, and Y.Zhang, 2010: Numerical simulation of sediment transport and morphological change of upstream and downstream reach of Chi-Chi Weir. In: Angermann, L. (Ed.), Numerical Simulations - Examples and Applications in Computational Fluid Dynamics, InTech, 311-326, doi: 10.5772/12994. [Link]

Yeh, K. C., C. T. Liao, Y. H. Chiu, J. B. Wu, C. J. Chen, and S. T. Wei, 2011: Study on Channel Migration and Stable Water Supply Alternatives of Kao-Ping Weir Reach after Typhoon Morakot, MOEAWRA1000236, Southern Region Water Resources Office, WRA, Taiwan.

Yeh, K. C., C. T. Liao, and S. T. Wei, 2012: Study on Stable Water Supply Strategies of Kao-Ping Weir in Response to the Overall Bed Deposition, MOEAWRA1010185, Southern Region Water Resources Office, Taiwan. 